\title{
Low Voltage Paper Electrophoretic Studies on Gonadotropin
}

\author{
Kenji YAGO \\ Department of Obstetrics and Gynecology, School of Medicine, \\ Tokyo Medical \& Dental University, Tokyo, Japan \\ (Director : Professor Kyushiro Fujii, M.D.)
}

There are two kinds of gonadotropin excreted in the urine, viz., pituitary gonadotropin and chorionic gonadotropin, both of which are proteohormones. The present study was designed to investigate the electrophoretic characteristics of the two proteohormones by separating the two compounds by means of paper electrophoresis, and determining the position of the gonadotropically active component on the electrophoretic pattern by bioassay. The gonadotropin materials used in this study were as follows: Hypohorin, a freezedried anterior pituitary preparation, powdered desiccated anterior pituitary preparation, and HCG powder, a placental preparation extracted from placenta taken during the early stage of pregnancy and also from the latter stage of pregnancy. Gonadotropin in the urine was extracted by the carbowax concentration method as previously reported.

Kobayashi's method of paper electrophoresis was employed in this study. Simultaneously and parallel to the gonadotropin preparation, human blood plasma of known electrophoretic characteristics was also run in order to determine the relative mobilities (R-Alb) of each fraction of gonadotropin in relation to albumin of blood plasma. The gonadotropic activity of each fraction was determined by the uterine weight method using young mice.

Pituitary gonadotropin exhibited 5 staining zones and the gonadotropic active fraction was detected in the R-Alb VI and VII fractions, i.e., in the zone corresponding to the $\alpha_{2}$ aspect of $\beta$-globulin fraction of human blood serum. Chorionic and placental gonadotropin also exhibited 5 staining zones. The gonadotropin active fraction was detected in the R-Alb V and VI fractions, i.e., in the zone corresponding to $\beta$-golbulin and $\gamma$-globulin fractions of human blood serum.

Samples taken from the urine of pregnant women both during the first and third trimesters exhibited 4 staining zones, and gonadotropin active zone was detected in the R-Alb VI fraction, i.e., in the region corresponding to $\beta$-globulin of human blood serum. Samples taken from the urine of climacteric women by the carbowax method alone did not exhibit any staining zone; however, when the ammonia alcohol precipitation method was also used, a gonadotropin active zone was detected in the region corresponding to the $\beta$ - and $\gamma$-globulin fractions of human blood serum.

From the aforementioned data, it is evident that the electrophoretic of pituitary gonadotropin and chorionic gonadotropin differ with each other, i.e., they have different mobilities. The active zone of the pituitary ganodotropin lies mostly in the region 
corresponding to $\alpha$-globulin fraction of human blood serum, and the placental gonadotropin in the region corresponding to $\beta$ - and $\gamma$-globulin fractions of human blood serum. It is assumed that the gonadotropin excreted in the urine has an active core with conjugated protein.

(pp. 1204 1216) 


\title{
低電圧濾紙電気泳動法による Gonadotropin の研究
}

\author{
東京医科歯科大学医学部産婦人科学教室（主任 藤井久四郎教授） \\ 矢後謙次
}

(炤和 41 年 5 月 24 日受付)

I 緒 言

尿中に排泄される $\mathrm{G}^{1}$ 亿は脳下垂体前葉を分泌源とする下垂体性 $\mathrm{G}$ と，胎艋絠毛組織を分泌源とする絨毛 性 G との二種類があり，それぞれ生物学的作用の上から下垂体前葉性 Gは FSH 作用, LH作用及び Luteotropic 作用を有し，絨毛性Gは主としてLH作用を有することは孟知の事である．之等のGは他の脳下垂体 ホルモンと共にいづれも蛋白性ホルモン (Proteohormone) $)^{23} 3$ ) である事からその化学的研究は主として蛋白 質化学の進歩によつて支えられて来た。近年に於ける蛋白質化学の急速な進歩に伴い，Proteohormoneに関 する研究方法も著しく開拓されGの抽出法や測定法についても化学的分野から多くの研究改良か泇えられて 来たがGの化学的性質に関してはまだ充分な解明が得られていない現状である.

著者は生化学的立場から尿中 G 在 Carbowax 法 $^{4}{ }^{5}$ によより抽出し低電圧滤紙電気泳動法により分離し, 各 分画を幼若マウス子宮重量法 $\left.{ }^{6}\right)$ につてその生物学的括性を測定しGの泳動特性の検討を行つた。即ち従来 滤紙電気泳動法によるGの泳動に関しては幾多の報告があり泳動像に表われた分画の比較やその部位の生物 学的. 化学的研究が加えられているが，電気泳動によつて規定されるこれらの物質の性格は，それらの示す 易動度(mobility)の検討にあるべきにも拘らず此の観点に立つてGの泳動を吟味した報告は見られなかつた。 この見地から著者は既知の泳動特性を有する Standard として健常人血清を選び，之と G 製片及び尿中 $\mathrm{G}$ と を同時平行泳動を行い，下垂体性 $\mathrm{G}$ と䋐毛性 $\mathrm{G}$ とが泳動学的に如何なる特性を示すかを検討し考察を加えた ので報告する。

\section{II 実験材料並びに実験方法}

\section{1 実験材料}

i) G 製 剂

実験に使用した $\mathrm{G}$ 製剤は五種類であり下垂体性 $\mathrm{G}$ として哺乳動物の下垂体前葉から抽出したHypohorin (帝臓) 及び同精製末 (三全)を，縅毛性 $\mathrm{G}$ としては妊娠初期絨毛及び満期胎盤から抽出した HCG 未(Human chorionic Gonadotropin) (帝臟)を，更に両者の混合性Gとして Synahorin（帝藏）を用いた。

ii) 採尿

約 $1 \%$ の割合に marfamin 液を入れた蓄尿瓶に妊娠尿及び更年期尿を 24 時間貯え，Gの抽出にはての中 から $200 \mathrm{ml}$ 使用した。

\section{2 実験方法}

尿中Gの抽出には種々の方法が行なわれているが，原尿そのままではGの含有量が 少く又生物学的検定 
に際しても毒性が強いので不適当であり，尿中 $\mathrm{G}$ の収量を上げる為には如何にして G 有効成分の損失 を少くして尿を濃縮するかが問題となつていた，著 者は本学生化学教室共同研究者が考案したFig. 10 如き装置により低蛋白体液の迅速濃縮を行うCarbowax法を応用して尿の濃縮を試みた。乙れはCarbowaxの有するる強力な吸水作用を利用して尿を透析 濃縮を行う方法で, 本法によれば尿中の塩類や残余 窒素等の小分子の物質は透析の過程で除かれ，加圧 気化法や凍結乾燥等の如く同時に塩類その他の不要 物質の濃縮を行う心配がなく, 又蛋白の変性を来た す恐れもなく且つ, 簡単な装置で容易に短時間に G の収量をあげる事が出来る等の諸特長を有するので 尿中Gの抽出には優れた方法として応用することが 出来た。尿の濃縮には平均分子量6000の Carbowax をFig. 1 の如く底の扁平なる濾斗代ガーゼを敷きそ の上に入れ，その上にセロファン膜を底にした円筒

に尿を入れて接触させると尿中の小分子のものは水分と共にセロファン膜外の Carbowax の方へ渗出し， $200 \mathrm{ml}$ の永は平均48時間でほほ糊状に濃縮するととが出来た。

\section{ii）低電圧濾紙電気泳動装置}

\section{1）濾紙電気泳動装置}

小林式濾紙電気泳動装置 (Fig. 2) を用( ${ }^{778)}$ )緩衝槽は 4 個使用して図の如く同時に 3 枚の泳動が出来る様 に直列に接続した．左右の両極槽には $1 \%$ の塩化カリ寒天ブリツヂにて連絡した。緩衝液及び塩化カリ溶液 は通電中にphの変化を来たすのを防ぐ為, 使用の都度新らたに調製したものを使用した。

\section{2) 緩衝液}

Michaelis によつて系列的にphを記載した Veronal-Veronal Na Buffer のうち ph8.6と規定された原液 (Veronal $1.84 \mathrm{~g}$ veronal Na 10.3g を Aq destにて1lにしたもの)を使用した.

\section{3) 滤紙及び試料の添加}

Whattman No. 1 の濾紙を幅 $12 \mathrm{~cm}$ 長さ $24 \mathrm{~cm}$ 亿切り, その幅を 4 等分にしてその一つに健常人血清を, 他の 3 つに試料をミクロピペットにて原線に線状に添加した。添加量は本実験では主として定性を目的とし

Fig. 2. Kobayashi's low voltage paper electrophoresis apparatus structure of cell inside

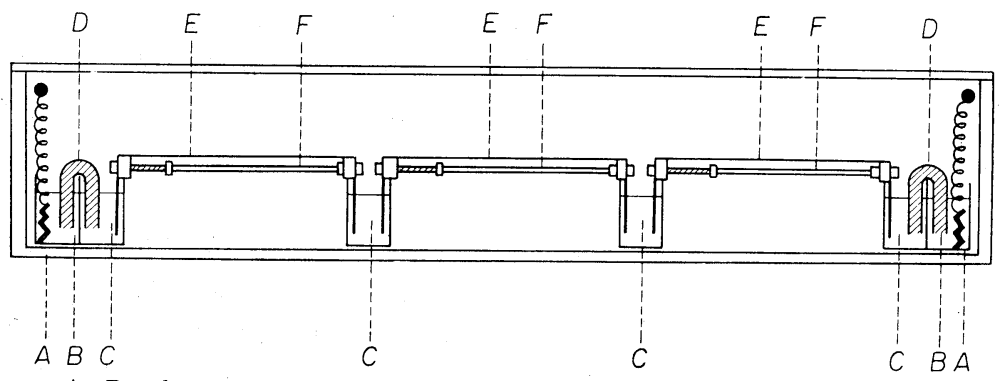
A. Pt plate
B. Plate cell
C. Buffer cell
D. Agar bridge
F. Paper fixation bar 
たので 1 回の添加量は略原線上に飽和するまでとし, 又添加の際血清と試料の混合するのを防ぐ為に各境界 に幅 $1 \mathrm{~mm}$ の溝を切りとつて泳動した.

\section{4）泳動条件及び通電時間}

泳動に際して通電量を一定に保つ場合，定電流方式をとるか定電圧方式をとるかはまだ確定した結論は出 ていないが，本実験では荷電粒子のイオン活性度から考えて定電流条件で泳動した，即ち滤紙幅 $12 \mathrm{~cm}$ 亿対 して $6 \mathrm{~mA}(0.5 \mathrm{~mA} / \mathrm{cm})$ の定電流で泳動し，時間は同時に平行泳動した人血清のAlbumin が原線より約 6 〜 $7 \mathrm{~cm}$ 泳動した時に電流を断つた。乙れ亿要する時間は約 5 〜 時間であつた.

\section{5）染色及び固定}

電流を断つた後濾紙を $100^{\circ} \mathrm{C} の$ 乾燥器中に約 5 分間入れて乾燥し, B.P.B. (Brom-Phenol-Blue) 染色液に20 分間つけて染色した。脱色は $0.5 \%$ 醋酸水溶液で数回とりかへ洗涤し，Background が白くなるまで行い室 温にて風乾後泳動像の濃度を一定に固定する為，BPBをアンモニア蒸気で発色させた．更に加熱融解したパ ラフィン液に通して固定し濾紙の透明化を行つた。

\section{6）易動比及び分画濃度の測定}

R-Albumin の概念に基き, 原線と血清アルブミンの泳動せる距離を基準にこれに対する各泳動物質の泳 動距離の比, 即ち R-Alb を決定してれを易動度とした。各泳動像の濃度は小林式光電光度計にて測定した。

iii) 生物学的検定法

\section{i) 滤紙分画法}

Fig. 3.

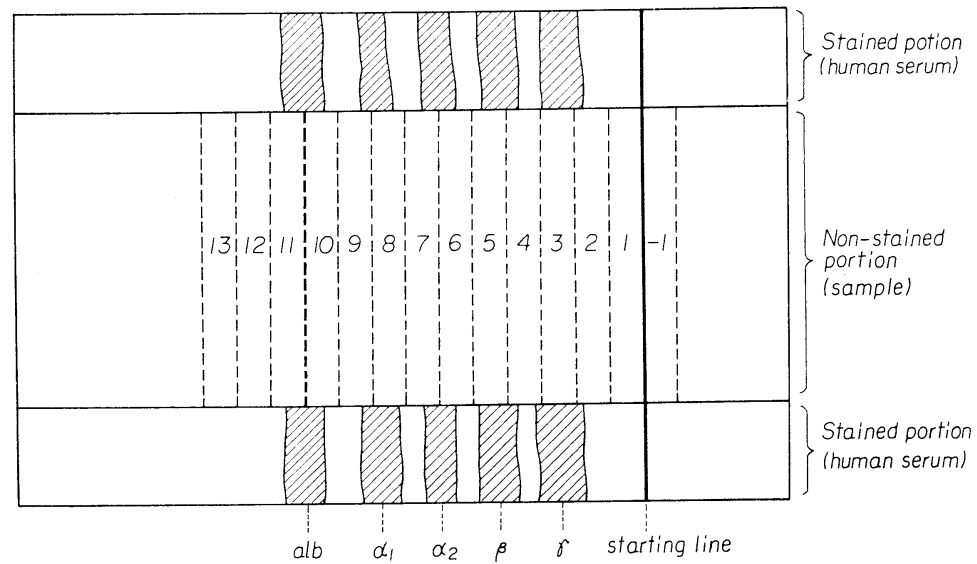

各泳動物質の濾紙からの抽出法はFig. 5 の如く濾紙の上下の両側を切り取りBPB染色を行い，残りの未染 色の部分について原線とアルブミンとの距離を10等分し，各区画濾紙を小試験管に入れた生食水につけて攪 拌圧出し G t溶出させた。この際 1 枚の区画濾紙ではGの有効成分が微量の為, 1 回の生物学的検定には同 様の条件の区画濾紙を15枚使用した。

\section{2) 幼若マウス子宮重量法}

生物学的検定に使用した幼若マウスは生後21日目の体重 7 ～gのメスD.D.系マウスで， 1 検体につき 1 群 3 匹を使用した。即ち検体を $3 \mathrm{ml}$ 亿溶出したものを 1 日 1 回 $1 \mathrm{ml}$ 宛 3 日間連日皮注し，最後の注射後 24 時間目に開腹し子宮を剔出し濾紙上で子宮内容を压出し周囲の結合織を取除いた後 Torsion Balance で科 量した。 $\mathrm{G}$ 活性の単位は 1 群の平均子宮重量を求め, 閉経期婦人尿から抽出したG力価の HMG (Human menopausal Gonadotropin) 単位を Standard として換算した HMG 単位で表わした。 


\section{III 実 験 成 績}

\section{G製剂試料の泳動像}

\section{i) 下垂体性Gの泳動像}

Hypohorin 及び下垂体前葉から抽出したG 精製末では BPB 染色による泳動像は稍不鮮明な分画を含め て共に略 $3 つ$ Fraction を認めた。(Fig. 4). 即ち Hypohorin では同時平行泳動した人血清の Albumin 位(R-Alb 10，11分画）と $\alpha_{2}$ 位 (R-Alb 7 分画) 及び $\beta$ との中間位 (R-Alb 3分画) に認め，下垂体性G末 (三全)では $\alpha_{1}$ 位 (R-Alb 8分画) と $\alpha_{2}$ 位の稍 $\beta$ 位寄り (R-Alb 6分画) 及び $\gamma$ 位 (R-Alb 3分画) に相当して泳動 する事がわかつた。

\section{ii）絨毛性Gの泳動像}

妊娠初期䄉毛から精製した $\mathrm{G}$ 末の試料は，生食水に対する溶解が悪く，泳動後原線に残る蛋白成分の混入 があり，染色上の分画は下垂性Gに比して多数の分画からなつていた。

Fig. 4. Biological activity of gonadotropin fractionated by paper electrophoresis

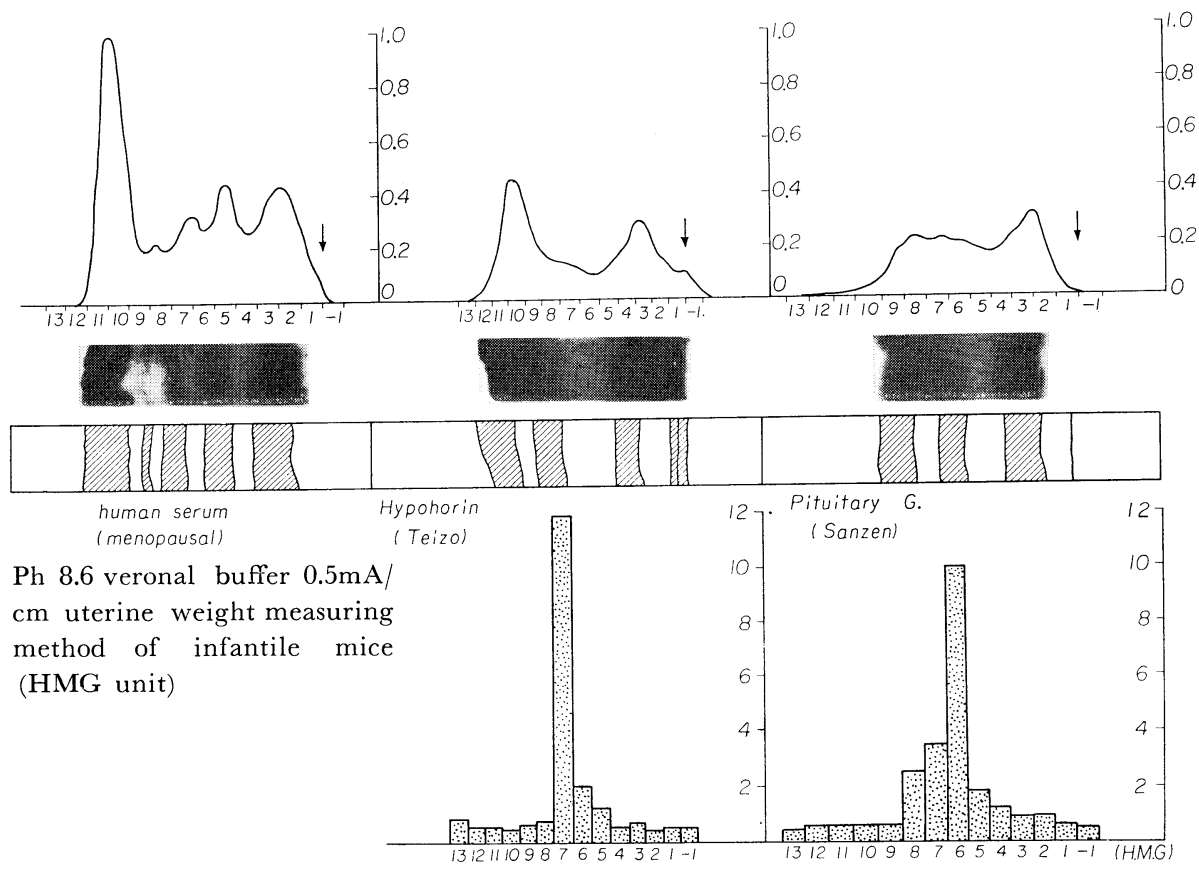

各分画の分離はよくないがFig. 5 の如く原線上に残る分画を含めて略 $5 つ$ Fraction がみられた. 即ち 同時平行泳動の人血清の Albumin 位 (R-Alb 10分画) $\alpha_{2}$ 位 (R-Alb 7分画) $\beta$ 位 (R-Alb 5分画) $\gamma$ 位 (R-Alb 3 分画) 及び原線に相当していた。 てれに対して満期胎盤性 $\mathrm{G}$ 末では生食水に対する溶解がよく, 原線には殆 んど残らず，可染分画も略 $5 つ$ Fraction を浔めた。即ち Albumin 位 (R-Alb 10分画) $\alpha_{1}$ 位 (R-Alb 8

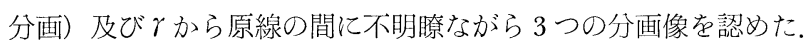

iii）混合性Gの泳動像

下垂体性 G と絨毛性 G とを $9 ： 1$ の割合に混合した協力性Gである Synahorin の泳動像はFig. 6の如く, Hypohorin の泳動像とよく似ており，2つの分画を示した. 之は同時平行泳動の人血清の Albumin 位及 
Fig. 5. Biological activity of gonadotropin fractionated by paper electrophoresis
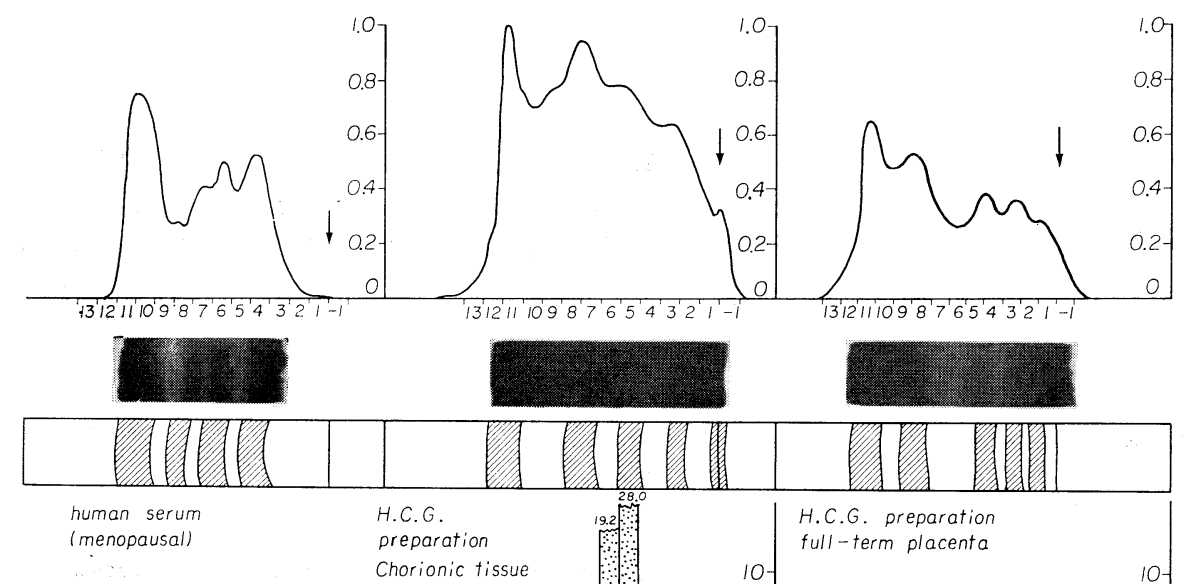

$\mathrm{Ph} 8.6$ veronal buffer $0.5 \mathrm{~mA} / \mathrm{cm}$ uterine weight measuring method of infantile mice (HMG unit)

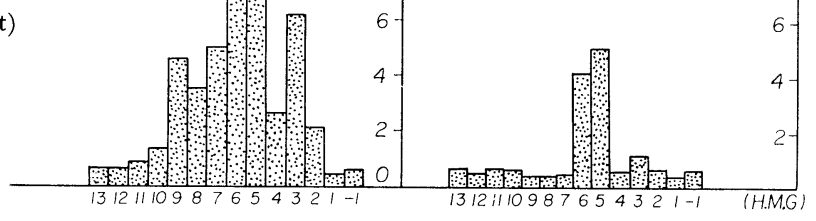

Fig. 6. Electrophoresis of gonadotropin preparations
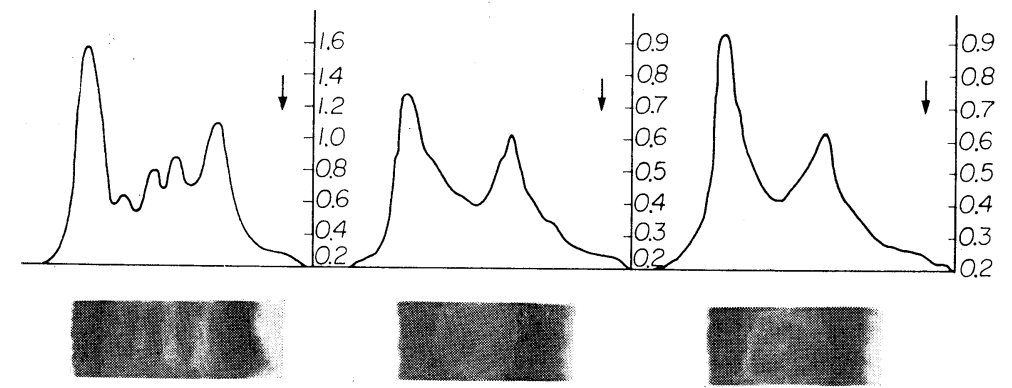

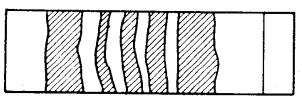

Serum

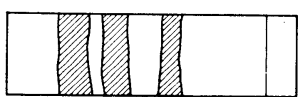

Hypohorin

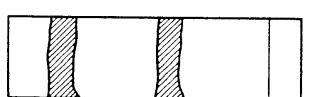

Synahorin

び $\beta$ 位に相当していた：乙れは大部分が下垂体性 $\mathrm{G}$ 含む為であると考えられた。

\section{G製剤の泳動像に対する生物学的検定}

泳動分画を前述の 10 等分法で分割溶出した検体を幼若マウス子宮重量法で生物学的に検定した結果，G活 性の部位は泳動像で認めた各分画とは必らずしも一致せず B.P.B の可染分画のすべてが Gの有効成分では なかつた。

\section{i) 下垂体性Gの生物学的検定}

Hypohorin 及び下垂体性G末の生物学的検定の結果， G活性の有効部位はFig. 4 の如く Hypohorinでは 第 7 分画に集中して著しい活性を認め，その前後にも若干の活性を認めた. 之に対して下垂体性 $\mathrm{G}$ 末 (三全) 
でも Hypohorin と略同様にG有効部位は第 6 分画に集中しており第 7 , 第 8 分画にも若干の活性を認めた。 てれは人血清の $\boldsymbol{\alpha}_{2}$ 位に略一致していた。

\section{iii) 絨毛性Gの生物学的検定}

初期䋐毛性 Gの泳動像に対する生物学的検定では，G活性の部位はFig. 5 の如く下垂体性Gに比べて明ら かなピークを示さないが，非常に強くG活性の反応を示し，乙れは略 $\beta$ 位(R-Alb 5-6分画)に最も強く表わ れ， $\alpha_{1} \alpha_{2}$ 位及び $\gamma$ 位にも可なりの活性を有していた。 これに対して満期胎盤から抽出精製したG末では初 期緁毛性に比して反応は弱いがG活性の部位の分離は可なり明膫で, 同時平行泳動した人血清の $\beta$ 位 $(\mathrm{R}-\mathrm{Alb}$ 第 $5 ， 6$ 分画）に相当しており，乙れは初期絨毛性 Gの活性部位と同じピークに存在していた.

3 . 更年期尿中 Gの泳動と生物学的検定

去勢婦人尿及び既に卵巣機能の低下した更年期後の婦人尿では下垂体性 Gが非常に増加している事から， 尿中の下垂体性 $\mathrm{G}$ の泳動には之等の婦人尿を用いて検討した。即ち更年期婦人尿を24時間防窗蓄尿し，その 中の $200 \mathrm{ml}$ を前述の Carbowax 法によつて透析濃縮し，Decicater 中に保存した試料を $0.02 \mathrm{ml}$ の生食水に 溶解してミクロピペットにて濾紙に線状に添加し泳動を行つた。 その結果Fig. 7 の右に示す如く検体は殆ん ぞ泳動されず原線上に残つており, 又生物学的検定によるG活性はいづれも1HMG 単位以下であつた。 そ

Fig. 7. Biological activity of femal menopausal urine fractionated by electrophoresis

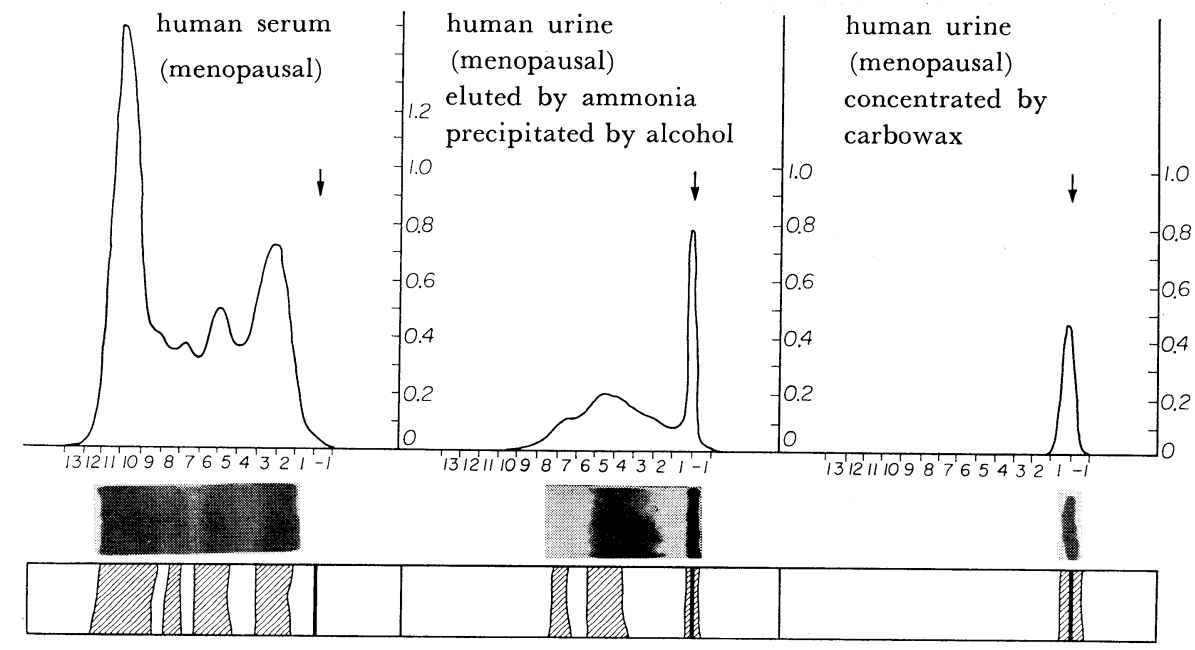

$\mathrm{Ph} 8.6$ veronal buffer $0.5 \mathrm{~mA} / \mathrm{cm}$ uterine weight measuring method of infantile mice

(H.M.G. unit)

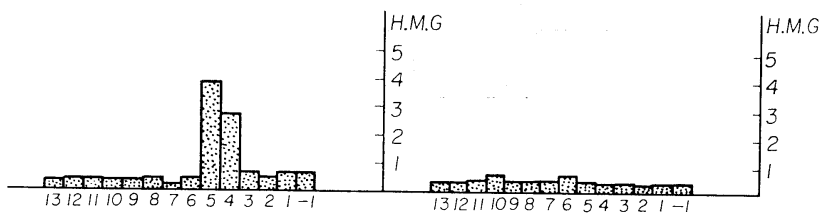

こで試みに Carbowax で透析濃縮した試料を更にアンモニアで再抽出し，アルコールで沈搌させたものを 試料として泳動してみるとFig. 7 の中央に示す如く, 同時平行泳動した人血清の $\beta$ 位から $\gamma$ 位にかけて泳像 分画像が得られ，生物学的活性の測定でもとの可染分画に一致してG活性の存在する事がわかつた。 即ち下 垂体性 $\mathrm{G}$ 末と更年期尿中 $\mathrm{G}$ と比較検討すると前者では $\beta$ から $\alpha$ 位寄りに存在するのに対して後者の尿中 $\mathrm{G}$ では逆に $\beta$ から $\gamma$ 位寄りに存在しており，乙れは下垂体から直接抽出した $\mathrm{G}$ と尿中 $\mathrm{G}$ とは泳動学的にも異る 態度を示し又アンモニア・アルコール法で再抽出した後に初めて生物学的活性が認められた事はアンモニア によつて尿中Gの抱合型蛋白が分解された結果活性を発現する様になつた事と考えられた。 
Fig. 8. Biological activity of gonadotropin from the urine of pregnant women

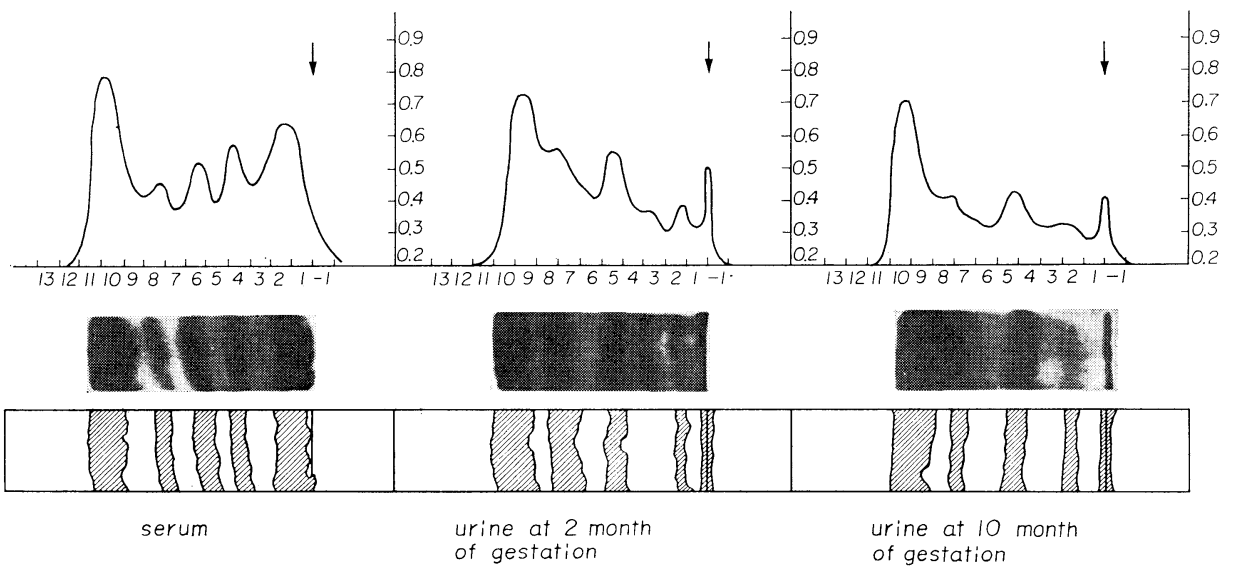

Urine concentrated by carbowax $\mathrm{Ph} 8.6$ veronal buffer $0.5 \mathrm{~mA} / \mathrm{cm}$ uterine weight measuring method infantile mice (HMG unit)

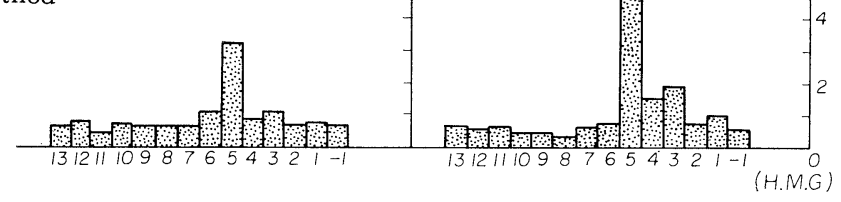

Fig. 9. Biological activity of gonadotropin from the urine of pregnant women

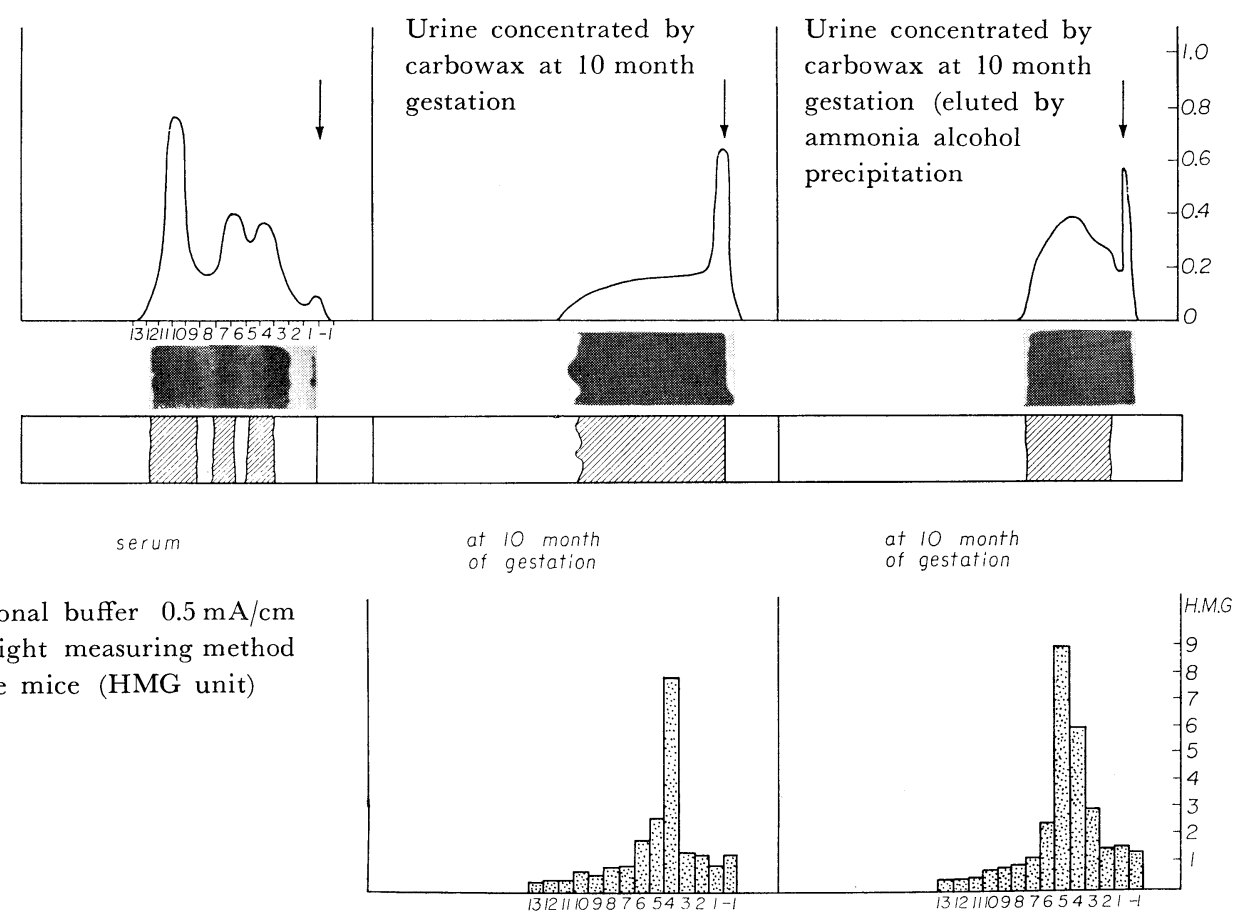




\section{4. 妊婦尿中Gの泳動亡生物学的検定}

妊娠時には絠毛組織及び胎艋に由来する絨毛性 $\mathrm{G}$ が尿中に多量に排泄され，娃娠初期と末期の尿中 $\mathrm{G} は$ 泳 動学的に如何なる態度を示すかを検討した。

\section{i) 妊娠初期尿中Gの泳動と全物学的検定}

妊娠初期尿から Carbowax 法により抽出した武料ではFig. 8 亿示す如く, 更年期尿とは異つてCarbowax 法のみの場合でも泳動された。即ち可染分画は多数見られ殊に Albumin 位及び $\beta$ 位に相当して強く染色さ れ，之を各区画について活性を測定した結果，G活性は絨毛から直接抽出した絨毛性 $\mathrm{G}$ 末に比して反応は弱 いが，初期絨毛性 $\mathrm{G}$ 末及び满期胎船性 $\mathrm{G}$ 末と殆んど一致した部位即ち， R-Alb 5 分画の $\beta$ 位に相当して $\mathrm{G}$ 活性が認められた，更に妊娠 2 力月尿についてもC Carbowax 濃縮後アンモニア・アルコール 沈澱法を併用 した結果は，Fig. 9右の如く，アンモニア・アルコール再沈澱法をしない場合と殆んど同じ泳動像を示し， ただ可染分画の濃度が強くなり，生物学的活性部位も同時平行泳動した人血清の $\beta$ 位に存在していた。その

Fig. 10. Biological activity of serum gonadotropin in pregnant women

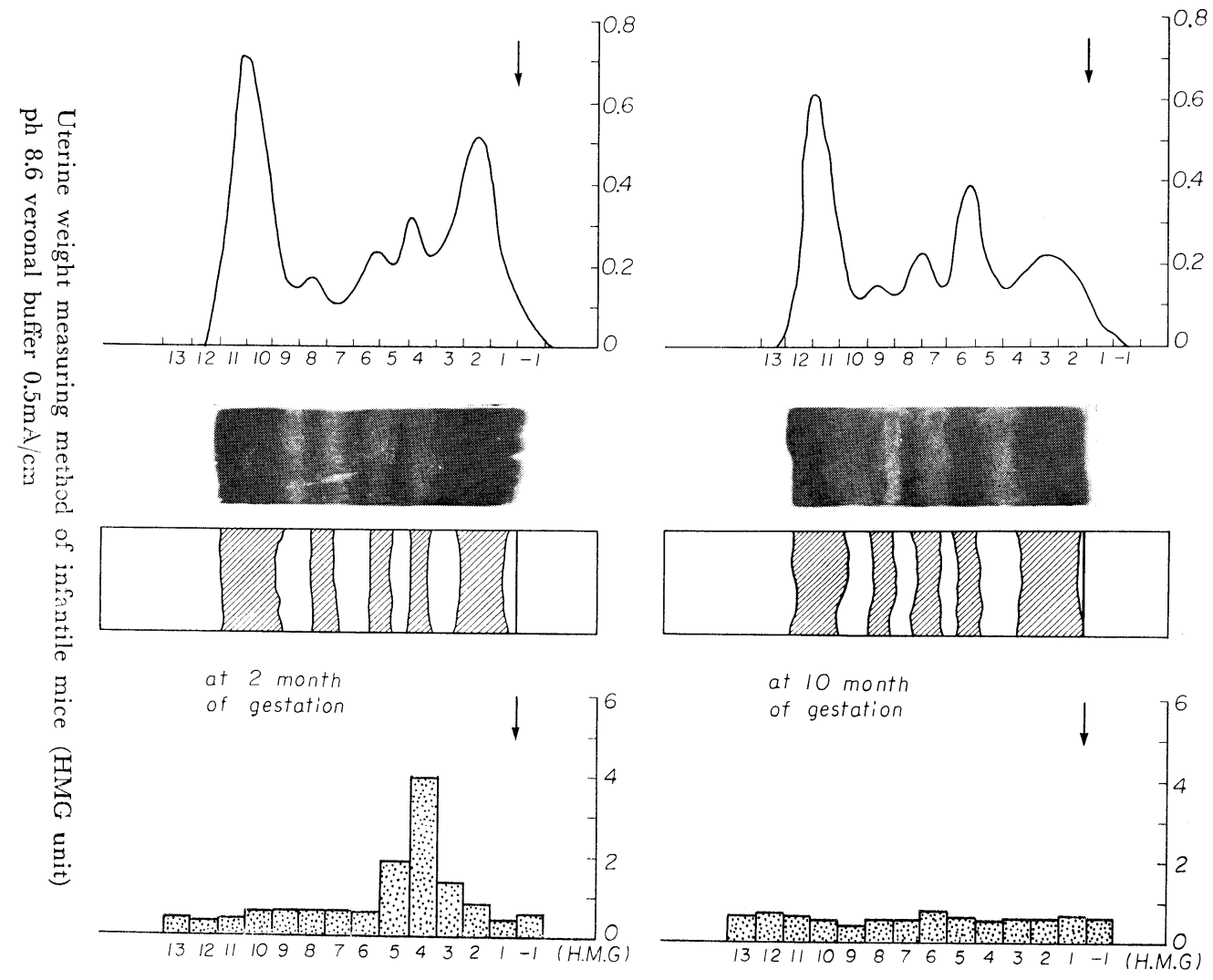

力価についてもアンモニア・アルコール沈澱法を併用した場合, 全体的に高值を示していた. 即ち更年期尿 中 Gがその蛋白構成に於いて抱合型を想定させるのに対して妊婦尿中Gでは遊離型のGが混在している事が 考光られた.

ii）妊娠末期尿中Gの泳動之生物学的検定

妊娠10力月尿についても同様に Carbowax 濃縮のみの試料と, 更にアンモニア・アルコール再抽出後の 試料と比較して泳動した結果は図の左の如く, Carbowax 濃縮のみでは娃娠初期尿に比して可染分画の濃度 が低く，泳動分画も不鮮明であるが，略 $\beta$ 位に相当して最も強い泳動像がみられ，生物学的活性でも同じく 
Fig. 11. Recovery of urinary gonadotropin
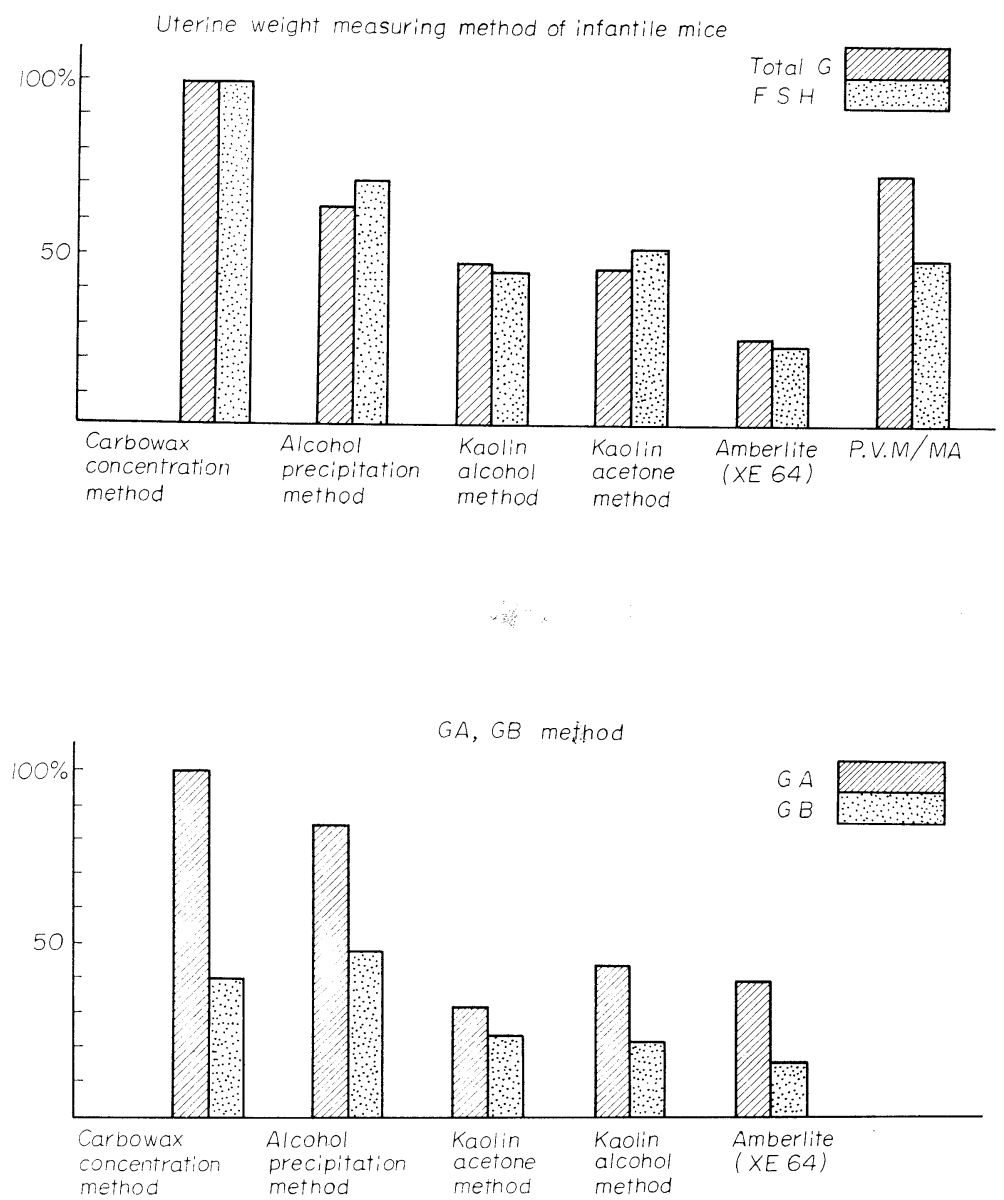

$\beta$ 位に一臸してG活性の存在を認めた。又更にアンモニア・アルコール再抽出した場合についても, 泳動像 は再抽出しない時と殆んど差がなく，鮮明な泳動像はみられないが生物学的活性は再抽出前と略同様に同時 平行泳動の人血清の $\beta$ 位にピークが存在することがわかつた，即ち妊婦尿では更年期尿と異つて初期及び末

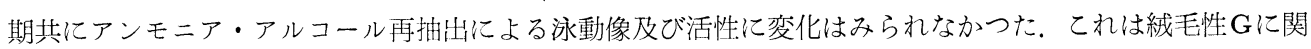
しては絨毛組織から抽出した試料を尿中から抽出した試料とは泳動学的に相異は認められず尿中Gはその蛋 白構成について絾毛組織性のGに近いものであるととが考えられた。

\section{5. 妊婦血清中Gの泳動と生物学的検定}

妊娠初期及び末期血清における Gの泳動と生物学的検定を行つた結果はFig. 10 の如く, 妊娠 2 力月及び10 力月の各分画易動度は勿論一定しているが Electrophotometer で測定した結果では妊娠 2 力月の血清は10 カ月の血清に比べて $\gamma$-Globulin が多く, 逆に妊娠10力月の血清は 2 カ月の血清に比べて $\beta$-Globulin の方 が多かつた, 又生物学的 $G$ 活性の部位は妊娠 2 力月の血清では R-Alb 第 4 分画即ち $\beta$ 位に相当して存在し

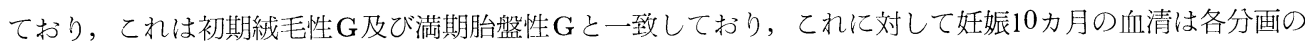
すべてが 1HMG 単位以下で生物学的にG有効成分が認められなかつたこてれは妊婦尿中 HCC の消長と 同様に妊娠初期血清中でも可なりの HCG の増加があると考えられた．妊娠末期では特にGの抽出操作を 
加えない限りでは血清そのものを試料とした場合は $\mathrm{G}$ 有効成分の存在を表わさない結果となるものと考えら れる。

\section{IV 考案並びに総括}

脳下垂前葉に由来するGが尿中に排泄されるてとは既に Zondek ${ }^{1)}$ (1930)によつて報告されているが，そ の排泄量は極めて少く, 更にGが高分子の蛋白性ホルモン Proteohormone $\left.{ }^{23} 3\right)$ であるてとがその単離に大き な障害となつて生化学的な研究は他の Steroidhormon 系に比して著しく遅れていた。しかし近年の蛋白質 化学のめざましい発展に伴い尿中 Gを高純度に分離しようとする試みは1950年以後非常な進歩をとげ，極め て多くの研究が多方面にわたつて行なわれる様になつた。

尿申から G 抽出する操作に関しては最も古くから用いられている方法としてアルコール沈澱法があるが， てれはZ Zondek が初めて尿中にGを発見した際に用いられたもので，滤過した弱酸性尿に 4 倍量のアルコ 一ルを加え，Gを蛋白成分と共に沈澱させる容易な方法である。 この方法は抽出に際し多量のアルコールを 必要をし更に G と共にアルコール不溶性の $\mathrm{G}$ 以外の不純物を同時に沈澱させる為，得られた $\mathrm{G}$ は極めて純度 が悪く, 毒性も強いので生物学的検定には不都合な事が多い欠点があつた。乙れを改良する為にその後種々 の方法が考えらられ，アルコール沈澱物を更に透析する方法 ${ }^{9}$ ， アルコールに代つてアセトンを溶媒とする 方法 ${ }^{10) 11}$ が考光られた。乙れらの方法は操作が容易でGの抽出法としては回収率も可なり高く再現性も良好 である点古典的な Standard として現在でも他の抽出法と比較検討する際に用いられる事もあるが routine な臨床的手段としては前述の様な難点が多い

ての観点に立つて更に蛋白沈澱剂にタングスラン酸 ${ }^{12)}$ 又はタンニン酸 ${ }^{13)}$ を使用したり, 又蛋白吸着法とし て安息香酸法 ${ }^{13}$ (や最近に至りカオリン ${ }^{15}$ (16)17)18)や水酸化アルミニューム ${ }^{19}$ )等で $\mathrm{G}$ を吸着抽出する方法等が行 われる様になつた。 ての他飽和硫酸アンモニウムによる塩折法 ${ }^{44}$ や尿中G 物理化学的に濃縮する方法とし て限外滤過法 ${ }^{20211}$ や超遠心分離法が報告されている，てれらの抽出法の優劣に関しては一定の見解がなく, $\mathrm{G}$ の収量, 毒性, 操作の難易性や費用等の点からそれぞれ一長一短があり，アルコール・アセトン沈澱法と 安息香酸吸着法及び水酸化アルミニュ一ム吸着法及びカオリン吸着法を比較し検討した実験 ${ }^{24}$ ではカオソン 吸着法が最も優れ，現在でも広く用いられ Loraine $\mathrm{e}^{25}$ 等も同様な見解を述べている。しかしながらてのカオ リン吸着法に於いても種々な難点があり，特にカオリンが天然性のものである事からカオリン自体の品質の 差による収量の変動は検定の際に生物学的反応に大きな影響を及ぼし, 又操作も幾分煩雑である事等が点 となつていた．ての点を改良した方法としてタングステン酸, タンニン酸法があり最近に至つてカオリンに 代つて合成イオン交換樹脂や更にイオン 交換セルローズを用いて下垂体中のGの分離 ${ }^{28}{ }^{29}{ }^{230}$ や尿中Gの分 離 ${ }^{3132}$ が行われる様になつたが，尚収量の点からその後余り普及されていない現状である。

著者は今回カオリン法沉かるものとしてCarbowax 6000 (Polyethylen Glycohol) を用いてGの濃縮を 試み，乙れをカオリンアルコール法 ${ }^{15}$ 及びカオリン・アセトン法 ${ }^{33}$ 及びイオン交換樹脂である Amberlite 法 $\left.\left.^{24}\right)^{27}\right)$ 及び古典的なアルコール沈澱法を比較検討した結果，Fig. 11 の如く生物学的検定法でも又，化学的 GAGB 法 ${ }^{34)}$ でも Carbowax 濃縮法では収量か約 2 倍以上にあり，又原尿 $200 \mathrm{cc}$ 亿対する抽出所要時間も可 なり短縮するてとが出来た，又 Carbowax の代りに安価な PVM/Ma ${ }^{29}$ (Polyvynilmethylether Maleinic acid の共重合体）を使用した結果でも所要時間の短縮が出来た，ての Carbowax 濃縮法の原理は先に述へ た如くCarbowax の有する強力な吸水能を利用して尿中の水分と共に Estrogen の如き低分子の物質及び 塩類等の毒性物質をセロファン膜外に排除する方法で，アルコール沈澱法に比して生物学的検定に際しての 毒性が少なく，又濃縮尿について Estrogen の混入の有無を藤井，藤山法 ${ }^{35}$ で検討した実験でも Estrogen の活性は認められなかつた。 Carbowax は分子量の大きい程吸水能力か強く Carbowax 300及び 1500では 吸水能力が低下し濃縮時間か涎長し，特に300を使用した場合は Estrogen の如き Steroid の混入の恐れが あり実用に供し得ない，又 Carbowax の代りに PVM/Ma を使用した実験では吸水能力は Carbowax よ り劣り, 且つとの物質は水に不溶性の為吸水膨化した後の処理に不便を感した。. 結果 Carbowax 6000 にょ 
る濃縮法は臨床応用に当つて抽出所要時間の短縮，操作の簡易化及び収量の增大等の点から最もすぐれた方 法として応用することが出来た.

Gの滤紙電気泳動に関しては, 近年になつて漸く盛んとなり, 各方面で研究され 1954 年 Stran \& Seeger ${ }^{36)}$ 等はGを含む物質を泳動し更にカオリン吸着後の尿中 HCG の泳動像から妊娠に特有な Fraction を認め た事を報しており，又 Schneider \& Frahn ${ }^{37}$ ) (1957) は滤紙電気泳動法による絨毛性Gが五つの分画に分かれ るととを認めその生物学的活性は第 3 第 4 分画に表われたと報告している. 又娃馬血清 $\mathrm{G}$ につてもその生 物学的反応加ら FSH作用の他に ICSH 作用も認められたと報じている。我国に於いても縅毛性Gの泳動に ついて梶原 $(1954)^{38)}$ ，小西 $\left.(1956)^{49}{ }^{400}\right)$ 等の発表があり䋐毛性Gの Fraction について検討を加え，更に1960 年古谷岸浪 ${ }^{11}$ の発表では HCG の Fraction は電気泳動学的特異性に関してはまだ不充分であることを報じ ている. 又, Winzler ${ }^{42}$ (1958) は Muco 蛋白体としてのGを泳動し，血清の $\alpha$-Globulin に一致して存在 すると述べている.

更に連続滤紙電気泳動法で脳下垂体性Gを FSH とL H V分離し，外来的に Anteron を下垂体剔出ラッ テに投与しその血清を泳動した結果 $\gamma$-Globulin 位に明暸な G 活性を認めたと望月 ${ }^{43}$ の報告がある.

従来Gの如き高分子の Proteohormone を電気泳動学的に追求しその泳動特性を検討する場合，単に染色 上に表われた Fraction の比較やその部分の活性検定では不充分であり再現性に乏しく, 試料を常に既知の 易動度を有する物質と同時平行泳動を行つてそのものに対する易動比を定めるてとが必要である. ての見知 から既知の泳動特性を有する Standard として健常人血清を選び, 之を同時平行泳動したGについてその泳 動特性を検討した。即ち人血清の Albumin に対し同じ条件で泳動した試料の泳動距離の相対的部位即ち R-Alb の概念を導入し, 生物学的検定は表われた Fraction に限らず Albumin と原線との距離を10等分 した各区画のすべてについて活性の有無を測定した。

先づ $\mathrm{G}$ 製剤についてみるとその泳動像は幾つかの分画に分かれるが，てれらの可染分画のすべてが有効分 画とは考学られないので泳動濾紙のすべてについて生物学的検定を行つた結果, 有効分画と考えられるもの と無效分画と考朰れるものとを明瞭に区別するてとが出来た．即ち可染分画の位置と生物学的活性を有す る分画とは必らずしも完全に重いてないない様に考光られるが，G有効分画が生物学的検定によつて決定さ れる G活性の位置は略一定しており，大体同時平行泳動した血清の $\beta$ 位を中心に泳動されることがわかつた。 更に各試料について示した結果を詳しく比較考察してみると次の閭題が提起される.

1. 下垂体性と胎盤性 G とは果して異る R-Alb をもつものであろうか, 即ちての両者が物理化学的にも 異る性格をもつものであれば電気泳動学的にも異る特性を示すと考光られるのでこの点から比較検討した結 果，今までの成績からみると下垂体 $\mathrm{G}$ の有効分画は人血清の $\beta$ 位より若干 $\alpha_{2}$ 位の方に位置し，乙れに対し て胎艋性 $\mathrm{G} は \beta$ 位及び若干 $\gamma$ 位側にズレて存在してた. 勿論ての推定は例数も少く又製剩試料の Lott も限 られているのでての結果のみから下垂体性 $\mathrm{G}$ と胎盤性 $\mathrm{G}$ とが電気泳動学に異つた特性を示すかどうか断定す るととは出来ないが今回の結果を一つの示唆として今後の検討に期待したいと思う.

2 次に今度の実験から上述の如く $\mathrm{G}$ 製剂の泳動像の可染分画と $\mathrm{G}$ 有効分画とが大体に於いて重畳してい たが，必らずしもすべての有効分画が完全に可染分画と一致していないで多少のズレがある様に思えた事は 既に述べたが，乙の結果から考觉ると有効分画は寧ら染色度が弱いのではなからうかを言う事も可能である と考元られた。即ち泳動像に表われた可染分画としての $\beta$ 位分画も或いは無効成分であり，その $\beta$ 位に重な り或いはその前後傮極染色性の悪い Fraction が有効分画として存在するのではなからうか, 換言すれば 真の有効分画は或は蛋白成分の少い，染色性の患いものであるか又は上述の染色法では表われず他の特殊の 染色法によつてのみ表われるのであるかと云う可能性も推定される。

3. 次に Carbawax 濃縮法による妊婦尿中 $G$ 亿ついて考察してみると, 妊娠初期及び末期共に生物学的 検定では R-Alb 5分画即ち $\beta$-Globulin 位に活性がみられた。乙れはG製剤としての絨毛性及び胎盤性 G の有効分画の存在する部位と略一致しており，尿中 $\mathrm{G}$ と藏器抽出性 $\mathrm{G}$ とは泳動学的に略一致した易動度をも つものであると考えられた。 
4. 主として下垂体性 Gを含む更年期尿については，Carbowax 濃縮のみでは明膫な分画はみられず，又 生物学的活性も認め引れなかつたが，Caobowax 濃縮試料を更にアンモニア・アルコールで再抽出，再沈淈 を加えた結果では，G活性は R-Alb の第 4 第 5 分画即ち $\beta$-Globulin 位に一致して可染分画があり，それ に重畳してG活性も認められた。即ち下垂体性Gに関しては更年期尿から抽出したGでは $\beta$-Glonulin 位に

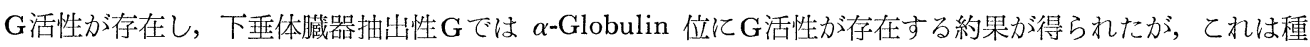
族も異り，尿中から抽出したものと下垂体臟器から抽出したものとの相違から易動度も買つて表われたもの と考学られた，又弤婦沓についても Carbowax 抽出のみの場合と Carbowax 抽出後アンモニア・アルコ 一ル再抽出法を併用した場合と老比較してみると，両者共に $\beta$-Globulin 位に一致しており，ただアンモ二 ア・アルコール法を併用した場合の方が HMG 単位で高値を示す結果が得られた。

以上の結果から考察してみると尿中の下垂体性 $\mathrm{G}$ は主として G活性型の蛋白体を有し，妊婦尿中のG 活性型のみならず活性型の蛋白体も有している結果, Crrbowax 濃縮のみでも G活性が表われるものと考光 られた，換言すれば，不活性型のG蛋白体が抢えらくアンモニア・アルコール法によつて分解される為に不 活性因子か除かれる結果Gの活性が表われる様になつたと考えられた。

\section{$\mathrm{V}$ 結 語}

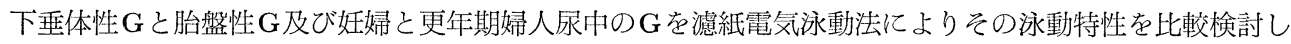
た結果次の推定を得た。

1. 下垂体性Gについて

電気泳動像は略五つの Fraction が認められたがその中生物学的活性を有す分画は R-Alb 第 6 第 7 分画 にあり，てれは同時平行泳動した人血清の $\beta$-Globulin 位より若干 $\alpha_{2}$ 位寄りに相当して存在していた。

2. 胎盤性 $\mathrm{G}$ につて

妊娠初期絠毛性 $\mathrm{G}$ 及び満期胎艋性 Gは共に泳動像では五つの可染分画に分れ，その生物学的活性は R-Alb の第 5 第 6 分画に認められ，乙れは同時平行泳動した人血清の略 $\beta$-Globulin 位に相当していたが若干 $\gamma$ Globulin 位にも存在していた。尚初期絨毛性Gはその活性が非常に強く $\beta$-Globuln 位をピークとして若 干その前後にも及んでいた.

3 ．妊婦尿及び更年期婦人尿中 Gについて

妊娠 2 力月及び10カ月尿では $\mathrm{G}$ 製剤に比して不鮮明であるが略四つの Fraction がみられ，生物学的活性 の存在したのは R-Alb の第6 分画でありてれは血清の略 $\beta$ 位に相当していた。更年期尿では Carbowax濃 縮法にアンモニア・アルコール法を併用した後始めて可染分画及び $\mathrm{G}$ 有效分画が浔められた。即ち泳動像で は $\beta$ から $\gamma$-Globulin 位にかけて可染分画がみられ，生物学的活性もその Fraction に一致して存在してい た.

4. 以上各種の Gonadotropin 芭電気泳動により比較検討した結果，下垂体性 $\mathrm{G}$ と胎盤性 $\mathrm{G}$ との間に泳動 学的に易動度の点があることを認め, 下垂体性 $\mathrm{G}$ は主として血清の $\alpha$-Globulin に附随して泳動し，胎盤性 Gは $\beta$ から $\gamma$-Globulin に附随してて泳動していると考元られ又尿中Gに関しては活性・不活性型の蛋白構 造を示す Active core の概念が想像された。

5. 妊婦血清のGについて

弤娠 2 力月の血清では $\beta$ 位に生物学的活性を認め, 妊娠 10 力月の血清では血清学のままを試料とした場合 では生物学活性は, どの分画にも認められなかつた。

稿を終るに臨み, 終始御想篤なる御持導御鞭㨍並びに御校閲を睗わつた恩師藤井久四郎教授並びに前生化学 教室宮本暲教授に衰心より謝意を表すると共に, 種々御協力並びに助言を戴いた助川幡夫博士, 熊坂高弘博 士, 根岸駿夫学士をはじめ教室員各位並に帝国臟器, 三全製薬に深謝致します。 
尚本研究は第34回日本内分泌学会総会シンポジュームの一部をなすものであり, 又との要旨は第24回日本 産科婦人科学会関東連合地方部会総会に於て発表した。

1) ZONDEK, B. : Klin. Wochenschr 2:964, (1930).

2) JOHNSEN, S.G. : Acta Endocrinol., 20: 106, (1955).

3) SEGALOFF, A. : Year Brok of Endocrinol.,266 (1955).

4) 宮本, 藤井, 坂岸, 野見山：生物物理化学, $3: 56$, (1956).

5) 藤井, 宮本他 : 臨産婦, $14: 1071,(1960)$. 6) 熊坂 : 臨産婦, $15: 203,(1961)$. 7) 藤井 : 臨産婦 $28: 441$, (1961). 8) 宮本, 杉本 : 滤紙電気泳動シンポジゥム，文光堂，(1958). $\quad 9$ ) HELLER, G.G. HELLER, E.J. : Endocrinol., 24:319, (1939). $\quad$ 10) DRIPS, D.G. \& OTERBERG, A.E. : Endocrinol., 23:703, (1938). 11) 松島：木と臨， $3: 796 ，(1955)$ 12) KATMAN, P.A. \& DOISY, E.A. : Proc. Soc. Exp. Biol \& Med., 30 : 1188, (1933). 13) LEVINE, L. : Endocrinol., 28:378, (1941).

14) KATMAN, P.A. \& DOISY, E.A. : J. Biol. Chem., 106:125, (1934).

15) BRADBURY, J.T. BROWN, E.S. \& BROWN, W.E. : Proc. Soc. Exper, Biol \& Med., $71: 228,(1947) . \quad 16)$ LORAINE, J.A. \& BROWN, J.B. : J. Glin. Endocrinol., 16:1180, (1956). 17) ALBERT, A. : Recent Prog. Horm. Rec., 12:227, (1956) 18) BROWN, P.S. : J. Endocrinol., 17:329, (1958).

19) MALBURG, R.F. \& GOODMAN, J.R : J. Clin. Endocr. \& Met., 14:666, (1945). 20) GORBMAN, A. : Endocrinol., 37:177, (1945). 21) VAN GILSE, H.A. : Acra Endocrinol., 21:19, (1956). 松本：日本内分泌誌，37：616，(1961). 23) JOHNSEN, S.G. : Acta Endocrinol., 20:106, (1955). 24）松島：木と臨，8:749，(1960) 25) LORAINE, V.A. : Vitam \& Horm., 14:305, (1956). 26) BUTT, W.R. GROOK, A.C. \& GUNINGHAM, F.J. Acta. Endocrinol., 30:378, (1959). 27) JOHNSEN, S.G. : Acta Endocrinol., 20:101, (1955). 28) STEELMAN, S.L. \& SEGALOFF, A : Abst. Endoc. Soc. 39th Meeting., 158:104, (1957). 29) 藤井, 熊坂, 矢後 : 小と臨, $11: 856$, (1963). 30) WOODS, M.C. \& SIMPSON, M.E. : J. Clin. Endocr. \& Met., 68:647, (1961). 31) STEElMAN, S.L. SEGAlOFF, A. AlBERT, A. \& ANDERSON, R.N. : Proc, Soc. Exper. Biol \& Med., 452, (1959). 32) ALBERT, A. KOBI, J. LEIFERMAN, J.R. DERNER, I. : J. Glin. Endocr. \& Met., $21: 1$, (1961). $\quad 33)$ BROWN, J.B. LORAINE, J.A. : J. Glin. Endocr., 16:1180 (1956). 34）助川：日産婦誌，11：1769，(1959)。35）藤井：第 9 回日産婦総会宿題報告 要旨, (1957). 36) STRAN, H.M. SCHNEIDER, W.G. : Acta Endocrinol., 95 : 162, (1954). 37) FRAHM, H. \& SCHNEIDER, W.G. : Acta Endocrinol., 24:106, (1957). 38) 梶原: 臨産婦, $8: 863,(1954)$. 39) 小西：应婦の世界，9:1451，(1957). 40) 同: ", $10: 214$, (1958). 41）古谷, 岸浪：日本不姓誌，5:500, (1960). 42) WINZLER, R.J. : Chem. \& Biol. of Mycopolysac., (1958). 43）望月：日本内分泌誌，37：780，(1961）. 44) JONES, G.E.S. \& BUGHER, N.I.R : Endocrinol., 32:46, (1943). 